\title{
Anestesia Venosa Total (AVT) em Lactente com Doença de Werdnig-Hoffmann. Relato de Caso *
}

\author{
Total Intravenous Anesthesia (TIVA) in an Infant with \\ Werdnig-Hoffmann Disease. Case Report
}

\author{
Marco Antonio Cardoso de Resende, TSA ${ }^{1}$, Elizabeth Vaz da Silva, TSA ${ }^{2}$, Osvaldo José Moreira Nascimento ${ }^{3}$, \\ Alberto Esteves Gemal, TSA ${ }^{4}$, Giseli Quintanilha 5; Eliana Maria Vasconcelos ${ }^{6}$
}

\section{RESUMO}

Resende MAC, Silva EV, Nascimento OJM, Gemal AE, Quintanilha G, Vasconcelos EM - Anestesia Venosa Total (AVT) em Lactente com Doença de Werdnig-Hoffmann. Relato de Caso.

JUSTIFICATIVA E OBJETIVOS: A doença de Werdnig-Hoffmann é a causa mais comum de hipotonia no lactente e quando presente logo após o nascimento tem pior prognóstico. Fraqueza muscular simétrica, arreflexia e fasciculações da língua são característicos. A maioria dos lactentes morre antes dos dois anos por insuficiência respiratória. O presente relato apresenta um caso com técnica venosa total durante anestesia.

RELATO DO CASO: Paciente feminina, branca, um ano, $10 \mathrm{~kg}$, estado físico ASA III, com doença de Werdnig-Hoffmann diagnosticada desde os dois meses de idade. Candidata à gastrostomia e fundogastroplicatura na técnica aberta e traqueostomia. Monitorização com cardioscópio, pressão arterial não invasiva, oxímetro de pulso, estetoscópio precordial e temperatura retal após venóclise. Foi préoxigenada e após bolus de atropina $(0,3 \mathrm{mg})$ foi realizada indução anestésica com remifentanil bolus $(20 \mu \mathrm{g})$ e propofol $(30 \mathrm{mg})$. Após intubação traqueal foi ventilada de forma controlada manual, em sistema sem absorvedor de $\mathrm{CO}_{2}$, Baraka (sistema Mapleson D), FGF de 4 L. $\mathrm{min}^{-1}, \mathrm{FiO}_{2}$ 0,5 $\left(\mathrm{O}_{2} / \mathrm{N}_{2} \mathrm{O}\right)$. Mantida sob anestesia com propofol $250 \mu \mathrm{g} \cdot \mathrm{kg}^{-1} \cdot \mathrm{min}^{-1}$ e remifentanil $0,3 \mu \mathrm{g} \cdot \mathrm{kg}^{-1} \cdot \mathrm{min}^{-1}$ em infusão contínua

* Recebido (Received from) do CET/SBA do Serviço de Anestesiologia e do Serviço de Neurologia do Hospital Universitário Antonio Pedro (HUAP) da Universidade Federal Fluminense (UFF), Niterói, RJ

1. Corresponsável CET/SBA HUAP-UFF

2. Professora Adjunta do Departamento de Cirurgia Geral e Especializada do HUAP-UFF; Responsável pelo CET/SBA HUAP-UFF

3. Professor Titular de Neurologia da Faculdade de Medicina da UFF; Coordenador da Pós-Graduação em Neurologia/Neurociências do HUAP-UFF

4. Professor Associado do Departamento de Cirurgia Geral e Especializada do HUAP-UFF; Coordenador da Pós-Graduação em Anestesiologia; Corresponsável pelo CET/SBA HUAP-UFF; Ph.D. em Anestesiologia pela Universidade de Bristol; M.Sc. Engenharia Biomédica

5. Mestre em Medicina (Neurologia) pela UFF; Médica Neurologista do Ambulatório de Neuropatias Periféricas do HUAP-UFF

6. Ex-Residente em Anestesiologia do HUAP-UFF; Anestesiologista do Hospital da Polícia Militar, Niterói

Apresentado (Submitted) em 20 de dezembro de 2008

Aceito (Accepted) para publicação em 24 de dezembro de 2009

Endereço para correspondência (Correspondence to):

Dr. Marco Antonio Cardoso de Resende

Hospital Universitário Antônio Pedro

Serviço de Anestesiologia

Rua Marquês de Paraná, 303, 3aar

Centro

24033-900 Niterói, RJ

E-mail: macresende@ig.com.br; macresende@gmail.com manual. O tempo cirúrgico foi de 150 minutos. O despertar ocorreu 8 minutos após o término da infusão, com ventilação espontânea. Duas horas depois foi transferida para unidade pediátrica e recebeu alta hospitalar no $4^{0}$ dia de pós-operatório.

CONCLUSÕES: A escolha da técnica anestésica prioriza a segurança que advém da familiaridade do manuseio dos fármacos existentes. Em crianças com doenças neuromusculares, a anestesia venosa total com remifentanil e propofol em sistemas de infusão, pela duração de ação extremamente curta, pode influenciar a evolução da doença favoravelmente.

Unitermos: DOENÇAS, Neurológica: atrofia muscular espinhal Tipo I (doença de Werdnig-Hoffmann); ANESTESIA, Geral: venosa.

\section{SUMMARY}

Resende MAC, Silva EV, Nascimento OJM, Gemal AE, Quintanilha G, Vasconcelos EM - Total Intravenous Anesthesia (TIVA) in an Infant with Werdnig-Hoffmann Disease. Case Report.

BACKGROUND AND OBJECTIVES: Werdnig-Hoffmann disease is the most common cause of hypotonia in infants and its prognosis is worse if it is present shortly after delivery. Symmetrical muscular weakness, areflexia, and fasciculations of the tongue are characteristic. The majority of the infants die before two years of age as a consequence of respiratory failure. The present report presents a case in which total intravenous anesthesia was used.

CASE REPORT: This is a 1 year old white female weighing $10 \mathrm{~kg}$, physical status ASA III, with Werdnig-Hoffmann disease diagnosed at two months of age. The patient was a candidate for open gastrostomy, fundus gastroplication, and tracheostomy. After venoclysis, the patient was monitored with cardioscope, non-invasive blood pressure, pulse oximeter, precordial stethoscope, and rectal temperature. She was oxygenated and, after bolus administration of atropine $(0.3$ $\mathrm{mg})$, boluses of remifentanil $(20 \mu \mathrm{g})$ and propofol $(30 \mathrm{mg})$ were administered for anesthetic induction. After tracheal intubation, she was ventilated with manual controlled system without $\mathrm{CO}_{2}$ absorber, $\mathrm{Ba}$ raka (Mapleson D system), FGF of 4 L. $\mathrm{min}^{-1}$, and $\mathrm{FiO}_{2} 0.5\left(\mathrm{O}_{2} / \mathrm{N}_{2} \mathrm{O}\right)$. Anesthesia was maintained with continuous manual infusion of propofol, $250 \mu \mathrm{g} \cdot \mathrm{kg}^{-1} \cdot \mathrm{min}^{-1}$, and remifentanil, $0.3 \mu \mathrm{g} \cdot \mathrm{kg}^{-1} \cdot \mathrm{min}^{-1}$. The surgery lasted 150 minutes. The patient regained consciousness 8 minutes after the end of the infusion, ventilating spontaneously. Two hours later, she was transferred to the pediatric unit, being discharged from the hospital on the fourth postoperative day.

CONCLUSIONS: The choice of anesthetic technique gives priority to the safety associated with the familiarity of handling available drugs. In children with neuromuscular diseases, due to the extremely short duration, total intravenous anesthesia with remifentanil and propofol in infusion systems can have a favorable influence on disease evolution.

Keywords: ANESTHESIA, General: intravenous; DISEASES, Neurologic: type I spinal muscular atrophy (Werdnig-Hoffmann disease). 


\section{Total Intravenous Anesthesia (TIVA) in an Infant with Werdnig-Hoffmann Disease. Case Report}

\author{
Marco Antonio Cardoso de Resende, TSA, M.D.; Elizabeth Vaz \\ da Silva, TSA, M.D.; Osvaldo José Moreira Nascimento, TSA, \\ M.D.; Alberto Esteves Gemal, TSA, M.D.; Giseli Quintanilha, \\ M.D.; Eliana Maria Vasconcelos, M.D.
}

\section{INTRODUCTION}

Type 1 muscular atrophy (Werdnig-Hoffmann) is a recessive autosomal disease of infants associated with degeneration of motor neurons in the anterior horn of the spinal cord. It is identified at birth or in the first months of life. The child does not develop the capacity to remain seated, to stand up or walk, but the intellectual capacity, sensorial exam, and sphincter control are preserved ${ }^{1-2}$. It is characterized by progressive symmetrical muscular weakness of the limbs, trunk, and head (except for eye muscles). Since it affects more severely the proximal muscles of the limbs, movements of the small muscles of the hands and feet can be observed. Atrophy and fasciculation of the tongue, as well as bulbar involvement, can be observed with progression of the disease. It evolves over a two- to three-year period with dysphagia, pulmonary aspiration, and death secondary to respiratory failure in the absence of mechanical ventilation ${ }^{3,4}$. The anesthesiologist must be aware of the comorbidities in case of any surgical intervention.

A wide phenotypical spectrum is seen in progressive muscular atrophy, whose classification is based on the age of onset of the clinical manifestations ${ }^{1}$. Four types are know: Type I (Werdnig-Hoffmann disease) is the most severe for affecting infants, being diagnosed up to six months of age, and the child is incapable of sitting up; Type II is the infantile chronic type, with onset between six and 12 months of age. The child is capable of sitting up, but incapable of walking; in Type III (Kugelberg-Welander disease), diagnosed between two and 15 years of age, the child is capable of walking; and Type IV has its onset in adulthood 5 .

Spinal muscular atrophy is the most common cause of motor neuron disease, affecting the brain stem and spinal cord in children. It is the second most common hereditary neuromuscular disease after Duchenne muscular dystrophy, with an incidence ranging from 1:10,000 to $1: 25,000^{2}$.

Ninety-eight percent of the patients with spinal muscular atrophy have homozygous deletion in the survival of motor neuron 1 gene (SMN 1), located in the $5 q$ arm (bands q 11.2-13.3). This gene is part of a complex protein necessary for the biogenesis of ribonucleoproteins. The absence or dysfunction of the $S M N$ causes an increase in neuronal death, and large scale deletions in the $5 q 13$ region are specific for WerdnigHoffmann disease ${ }^{6-7}$.

Degeneration of anterior horn cells causes secondary reduction in the production of choline acetyltransferase, which is involved in acetylcholine synthesis, increasing the sensitivity of the patient to depolarizing drugs. When using those drugs, dose titration and monitoring of the neuromuscular blockade is recommended. However, depolarizing blockade (succiniIcholine - Sch) should be avoided due to the association with hypercalcemia and myotonic type contractions ${ }^{8}$.

Very few information is available in the literature on the anesthetic management of hypotonic children ${ }^{9}$. Although hypotonia is a muscle-skeletal disorder seen in patients susceptible to malignant hyperthermia such as in central core disease or King-Denborough myopathy, a relationship between spinal muscular atrophy and the development of hyperthermia has not been observed. In the case of Werdnig-Hoffmann disease, several difficulties, almost always encompassing progressive muscular weakness and unpredictable response to neuromuscular blockers, should be considered, as well as the ethical discussion on the ventilatory support used ${ }^{10}$. Although inhalational anesthesia in patients with severe neuromuscular involvement is not prohibited, the intravenous technique without muscular blockade could be interesting ${ }^{11}$. The objective of this report was to present the case of an infant with WerdnigHoffmann disease undergoing surgery under total intravenous anesthesia.

\section{CASE REPORT}

This is a 1-year old white female with Werdnig-Hoffmann disease, diagnosed at 2 months of age, weighing $10 \mathrm{~kg}$. She was hospitalized the day before the surgery and intravenous hydration was instituted according to the prescription of the pediatrics clinic. She was bedridden, alert, with semi passive attitude, physical status ASA III, with enteral catheter, and without pre-anesthetic medication. The patient was transferred to the operating room in the morning for a open gastrostomy with fundus gastroplication and tracheostomy. She did not have other congenital disorders, although she had a history of two episodes of pneumonia probably due to aspiration over the last six months. Preoperative laboratorial exams included $\mathrm{Ht} 34 \%$,

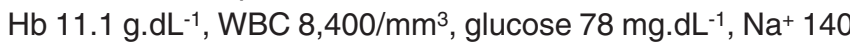
$\mathrm{mEq} \cdot \mathrm{L}^{-1}$, and $\mathrm{K}^{+} 4.4 \mathrm{mEq} \cdot \mathrm{L}^{-1}$. Lung auscultation revealed decreased breath sounds in both bases $\left(\mathrm{SpO}_{2} 96 \%\right.$ in room air). Monitoring included automatic non-invasive blood pressure, cardioscope $\left(D_{\|}\right.$and $\left.V_{5}\right)$, oxicapnography, precordial stethoscope, and rectal temperature. Another venoclysis was performed in the left upper limb with a 24G catheter followed by the infusion of cefazolin $(500 \mathrm{mg})$. After pre-oxygenation for five minutes with $100 \% \mathrm{O}_{2}$ and boluses of atropine $(0.3 \mathrm{mg})$, remifentanil $(20 \mu \mathrm{g})$, and propofol $(30 \mathrm{mg})$ were administered for anesthetic induction. The patient was intubated with a 4.5 ET tube without balloon and with no use of neuromuscular blockers. Capnography showed a normal curve. The patient was ventilated with the Baraka (Mapleson $\mathrm{D}$ ) without $\mathrm{CO}_{2} \mathrm{ab}$ sorber with FGF of $4 \mathrm{~L}$. min ${ }^{-1}$, $\mathrm{FiO}_{2} 0.5\left(\mathrm{O}_{2} / \mathrm{N}_{2} \mathrm{O}\right)$, and $\mathrm{FiO}_{2}$ of 1 during the tracheostomy. The skin was infiltrated with $0.3 \%$ ropivacaine $(20 \mathrm{mg})$ before the incision. General anesthesia was maintained with continuous manual infusion of propofol 
$250 \mu \mathrm{g} \cdot \mathrm{kg}^{-1} \cdot \mathrm{min}^{-1}$, and remifentanil $3 \mu \mathrm{g} \cdot \mathrm{kg}^{-1} \cdot \mathrm{min}^{-1}$ (through the venous access established earlier). The objective was to maintain HR between 80 and 100 bpm and SBP/DBP between 9070 and $50-40 \mathrm{mmHg}$, respectively. Minimal temperature was $36^{\circ} \mathrm{C}$. Warmed Ringer's lactate, $200 \mathrm{~mL}$, was administrated for hydration according to the estimates of Holiday and Segar $\left(4 \mathrm{~mL} . \mathrm{kg}^{-1} \cdot \mathrm{h}^{-1}\right)$ along with ventilation-related losses. At the end of the procedure, $500 \mathrm{mg}$ of intravenous dypirone were administered. The anesthetic-surgical procedure lasted 150 minutes, without intercurrences. Cardiorespiratory stability was maintained throughout the procedure, awakening eight minutes after the suspension of the anesthetics, with spontaneous ventilation. In the post-anesthetic recovery room, a chest X-ray showed good positioning of the cannula. After two hours, she was transferred to the semi-intensive pediatric unit where humidified air was administered, with frequent aspiration of secretions. She was discharged from the hospital on the $4^{\text {th }}$ postoperative day. The patient died after six months due to complicated pulmonary infection.

\section{DISCUSSION}

First described by the neurologists Giudo Werdnig and Johann Hoffmann at the end of the XIX Century, type I spinal muscular atrophy is a rare hereditary, progressive disorder that affects infants early in life, characterized by significant muscular hypotonia and weakness ${ }^{2}$. Affected patients have evolutive difficulties in swallowing due to brain stem involvement, besides dysfunction of the respiratory intercostals muscles. It has a somber prognosis, and death usually due to pneumonia occurs in the first three years of life. It does not have a specific treatment, and management of those patients should be multidisciplinary or multimodal.

The surgical procedures in the digestive tract of the patient presented here were aimed at reducing the risk of pulmonary aspiration and improving nutritional support. Tracheostomy allows adequate aspiration of secretions and facilitates mechanical ventilation, which is expected in the evolution of this disorder.

The literature does not have any evidence of the ideal anesthetic technique. Total intravenous anesthesia in children, with manual- or target-controlled infusion, became more widespread with the advent of short latency drugs, with fast arous$\mathrm{al}$, absence of cumulative effects, and ease of titration ${ }^{12}$. The coadministration of propofol and the ultrashort-acting opioid, remifentanil, has been used in children to facilitate tracheal intubation without neuromuscular blockade in elective surgeries 13,14 . When comparing the dose-response of remifentanil for intubation of healthy term infants (2-12 months) and children (1-6 years), Crawford et al. determined the $\mathrm{ED}_{98}$ as 2.88 $\mu \mathrm{g} \cdot \mathrm{kg}^{-1}$ and $\mathrm{ED}_{50}$ of $1.7 \mu \mathrm{g} \cdot \mathrm{kg}^{-1}$ with $3 \mathrm{mg} \cdot \mathrm{kg}^{-1}$ of propofol ${ }^{-1}$. The response was similar in both age groups with the prior administration of glycopirrolate $\left(10 \mu \mathrm{g}^{\mathrm{kg}}{ }^{-1}\right)$ and propofol $(4.0$ $\mathrm{mg} \cdot \mathrm{kg}^{-1}$ ) resulting in good intubation conditions with normal airways, besides hemodynamic stability ${ }^{15}$. The sequence of drug administration interferes with the time of onset of apnea, which was longer in the study of Morgan et al. with 4 mg. $\mathrm{kg}^{-1}$ of propofol and $1.25 \mu \mathrm{g} \cdot \mathrm{kg}^{-1}$ of remifentanil when compared to the same doses of propofol and succinylcholine ${ }^{16}$. Remifentanil has an organ-independent metabolism and it is considered the opioid of choice for children, and bradycardia and hypotension are less severe in this population of patients than in adults ${ }^{17}$. Bolus of this medication in anesthetic induction is controversial, since remifentanil was developed for continuous infusion, with fast onset and short duration of action ${ }^{18}$. Infusion with bolus doses and manually-controlled were used, but target-controlled infusion pumps can be of more advantage since they correct age-related pharmacokinetic parameters, with the increase in volume of distribution expected in children ${ }^{19}$. The predominantly suprathalamic actions of propofol did not delay recovery of the muscle tone in the clinical case in question in which the use of muscle relaxants should be minimized or abolished. The use of propofol should be avoided in prolonged procedures or sedation in intensive care due to the risk of propofol infusion syndrome, promoting metabolic acidosis, rhabdomyolysis, hyperlipidemic plasma, and cardiac arrest 17,20,21. The mechanism is unknown, but the presence of mitochondrial toxicity by propofol metabolites, or direct propofol effects that requires prolonged high-dose infusion, or a genetic variance of the clearance and metabolism of this drug has been especulated ${ }^{22}$. Propofol is considered safe for short procedures, both for sedation and general anesthesia. Several reports on the use of propofol in patients younger than three years, the lower age limit in which total intravenous anesthesia is not contraindicated, can be found in the literature. Higher doses of remifentanil seem to be necessary in pediatric patients than in adults to block the somatosensory response when propofol is used ${ }^{23}$.

Although myopathies, dystrophies, and channelopathies are rarely found in anesthetic practice, they do not always have a defined clinical-laboratorial diagnosis, and their diagnosis can remain uncertain. Hepatic and renal immaturity in children and the individual variability observed in intravenous anesthesia can represent limitations for the technique. However, inhalational anesthesia in patients with neuromuscular disorders should not be the technique of choice because the possibility of triggering malignant hyperthermia and rhabdomyolysis cannot be ruled out ${ }^{24}$. Werdnig-Hoffmann disease is considered a relative contraindication for inhalational anesthesia, mainly due to the risk of rhabdomyolysis ${ }^{25}$. The same intravenous agent - propofol - can cause acidosis and rhabdomyolysis in mitochondrial myopathies, but it can reduce the chances of rhabdomyolysis in patients with Werdnig-Hoffmann disease. When choosing an anesthetic technique, the safety associated with the familiarity of handling the drugs available is the first consideration. Due to their extremely short duration of action, total intravenous anesthesia with infusions of remifentanil and propofol in children with neuromuscular disorders can influence favorably the evolution of the disease. The technique without neuromuscular blocker was adequate; it was not associated with hemodynamic instability, thoracic rigidity, or difficulty to intubate. Deterioration of the respiratory function with negative postoperative effects for the patient was not observed either. 


\section{REFERÊNCIAS - REFERENCES}

01. Kaufman P, Finkel R - Learning to walk: challenges for spinal muscular atrophy clinical trials. Neurology, 2007;68:11-12.

02. Menkes JH, Sarnat HB - Diseases of the Motor Unit, em: Menkes JH, Sarnat HB - Child Neurology. $6^{\text {th }}$ Ed, Philadelphia, Lippincott Williams \& Wilkins, 2000;469-471.

03. Hardart MKM, Truog RD - Spinal muscular atrophy-type I. Arch Dis Child, 2003;88:848-850.

04. Cobben JM, Lemmink HH, Snoeck I et al. - Survival in SMA type I: a prospective analysis of 34 consecutive cases. Neuromuscul Disord, 2008;18:541-544.

05. Chung BHY, Wong VCN, Ip P - Spinal muscular atrophy: survival pattern and functional status. Pediatrics, 2004;114:e548-553.

06. Prior TW - Spinal muscular atrophy diagnostics. J Child Neurol, 2007;22:952-956.

07. Burlet $\mathrm{P}$, Burglen $\mathrm{L}$, Clermont $\mathrm{O}$ et al. - Large scale deletions of the $5 q 13$ region are specific to Werdnig-Hoffmann disease. J Med Genet, 1996;33:281-283.

08. Baranov D, Kelton $\mathrm{T}$, McClung $\mathrm{H}$ et al. - Neurologic Diseases, em: Fleisher LA - Anesthesia and Uncommon Diseases, $5^{\text {th }}$ Ed, Philadelphia, Elsevier, 2006;267.

09. Carvalho M - Anestesia para crianças hipotônicas. CEDAR, 2004;(24):4-7.

10. Bush A, Fraser J, Jardine $E$ et al. - Respiratory management of the infant with type 1 spinal muscular atrophy. Arch Dis Child, 2005;90:709-711.

11. Videira RLR, Cruz JRS - Remifentanil na prática clínica. Rev Bras Anestesiol, 2004;54:114-128.

12. Martins CEC, Albuquerque MAC, Simoni RF - Remifentanil, em: Bagatini A, Carraretto AR, Vianna PTG - Curso de Educação à Distância em

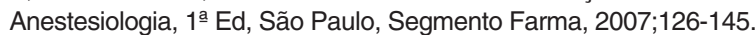

13. Ehran E, Ugur G, Gunusen I et al. - Propofol - not thiopental or etomidate - with remifentanil provides adequate intubating conditions in the absence of neuromuscular blockade. Can J Anaesth, 2003;50:108-15.

14. Batra YK, Al Qattan AR, Ali SS et al. - Assessment of tracheal intubating conditions in children using remifentanil and propofol without muscle relaxant. Paediatr Anaesth, 2004;14:452-456.

15. Crawford MW, Hayes J, Tan JM - Dose-response of remifentanil for tracheal intubation in infants. Anesth Analg, 2005;100:1599-1604.

16. Morgan JM, Barker I, Peacock JE et al. - A comparison of intubating conditions in children following induction of anaesthesia with propofol and suxamethonium or propofol and remifentanil. Anaesthesia, 2007;62:135-139.

17. Kretz FJ - The future of paediatric anaesthesia is total intravenous anaesthesia. Curr Opin Anaesthesiol, 2002;15:305-307.

18. Nora FS, Fortis EAF - Remifentanil: por que precisamos de outro opióide? Rev Bras Anestesiol, 2001;51:146-159.

19. Nora FS, Klipel R, Ayala G et al. - Remifentanil: o regime de infusão faz diferença na prevenção das respostas circulatórias à intubação traqueal? Rev Bras Anestesiol, 2007;57:247-260.

20. Wysowski DK, Pollock ML. - Reports of Death with use of propofol (Diprivan) for nonprocedural (long-term) sedation and literature review. Anesthesiology, 2006;105:1047-1051.

21. Wolf AR, Potter F - Propofol infusion in children: when does an anesthetic tool become an intensive care liability. Pediatr Anesth, 2004; 14:435-438.
22. Burow BK, Johnson ME, Packer DL - Metabolic acidosis associated with propofol in the absence of other causative factors. Anesthesiology, 2004;101:239-241.

23. Muñoz HR, Cortinez LI, Ibacache ME et al. - Remifentanil requirements during propofol administration to block the somatic response to skin incision in children and adults. Anesth Analg, 2007;104:77-78

24. Lerman J, Johr M - Inhalational anesthesia vs total intravenous anesthesia (TIVA) for pediatric anesthesia. Pediatr Anesth, 2009;19:521534.

25. Flick RP, Gleich SJ, Herr MMH et al. - The risk of malignant hyperthermia in children undergoing muscle biopsy for suspected neuromuscular disorder. Pediatr Anesth, 2007;17:22-27.

\section{RESUMEN}

Resende MAC, Silva EV, Nascimento OJM, Gemal AE, Quintanilha G, Vasconcelos EM - Anestesia Venosa Total (AVT) en Lactante con Enfermedad de Werdnig-Hoffmann. Relato de Caso.

JUSTIFICATIVA Y OBJETIVOS: La enfermedad de Werdnig-Hoffmann es la causa más común de hipotonía en el lactante y cuando está presente después del nacimiento su pronóstico empeora. La debilidad muscular simétrica, la arreflexia y las fasciculaciones de la lengua son sus características. La mayoría de los lactantes fallece antes de los dos años por insuficiencia respiratoria. El presente relato presenta un caso con la técnica venosa total durante la anestesia.

RELATO DEL CASO: Paciente femenina, blanca, de un año, 10 $\mathrm{kg}$, estado físico ASA III, con enfermedad de Werdnig-Hoffmann diagnosticada desde los dos meses de edad. Candidata a la gastrostomía y fundoplicatura en la técnica abierta y traqueostomía. Monitorización con cardioscopio, presión arterial no invasiva, oxímetro de pulso, estetoscopio precordial y temperatura rectal posterior a la venoclisis. Fue preoxigenada y después de recibir el bolo de atropina $(0,3 \mathrm{mg})$, se le realizó la inducción anestésica con remifentanil bolo $(20 \mu \mathrm{g})$ y propofol $(30 \mathrm{mg})$. Después de la intubación traqueal fue ventilada de forma controlada manualmente, en sistema sin absorvedor de $\mathrm{CO}_{2}$, Baraka, FAG de 4 L. min ${ }^{-1}, \mathrm{FiO}_{2}$ $0,5\left(\mathrm{O}_{2} / \mathrm{N}_{2} \mathrm{O}\right)$. Mantenida bajo anestesia con propofol $250 \mu \mathrm{g} \cdot \mathrm{kg}^{-1}$. $\mathrm{min}^{-1}$ y remifentanil $0,3 \mu \mathrm{g} . \mathrm{kg}^{-1} \cdot \mathrm{min}^{-1}$ en infusión continua manual. El tiempo quirúrgico fue de 150 minutos. El despertar se dio en 8 minutos después del término de la infusión, con ventilación espontánea. A las dos horas, fue transferida a la unidad pediátrica y recibió alta al $4^{\circ}$ día del postoperatorio.

CONCLUSIONES: La elección de la técnica anestésica prioriza la seguridad que proviene de la familiaridad del manejo de los fármacos existentes. En los niños con enfermedades neuromusculares, la anestesia general intravenosa con remifentanil y propofol en sistemas de infusión, por la duración de la acción extremadamente corta, puede influir en la evolución de la enfermedad favorablemente. 